\title{
Chemical Composition and Antibacterial activity of Essential Oil of Marrubium vulgare from Eastern Algeria
}

\author{
Abderazak Abadi ${ }^{1}$, Aicha Hassani ${ }^{2, *}$ \\ ${ }^{1}$ Laboratoire de Molécules Bio-active et Valorisation de la Biomasse, École Normale Supérieure, \\ BP 92, Kouba-Algiers, Algeria \\ ${ }^{2}$ Laboratoire de Chromatographie, Faculté de Chimie, USTHB, Algiers, Algeria \\ *E-mail address: ryadabadi@gmail.com
}

\begin{abstract}
The essential oil from flowering Marrubium (Marrubium vulgare L.) an aromatic member of the Lamiaceae family, from Algeria, obtained by hydrodistillation, was analysed by GC/FID and GC/MS. The constituents were identified by their mass spectra and Kovats' indices. Fivety (50) components in the oil of $M$. vulgare were identified. The results demonstrated that the major components of the essential oil were: 4,8,12,16-Tetramethyl heptadecan-4-olid (16.97\%), Germacrene D-4-ol (9.61\%), $\alpha$ - pinéne (9.37\%), Phytol (4.87\%), Dehydro-sabina ketone (4.12\%), Piperitone (3.27\%), $\delta$-Cadinene (3.13\%), 1-Octen-3-ol (2.35\%) and Benzaldehyde (2.31\%). Essential oil of $M$ vulgare was evaluated for its antibacterial activities against Gram-positive and Gram negative pathogenic bacteria: Bacillus subtilis, Micrococcus luteus, Escherichia coli and Klebsiella pneumoniae.
\end{abstract}

Keywords: Marrubium vulgare; Essential oil composition; GC/MS; antibacterial activities

\section{INTRODUCTION}

In recent years, essential oils of plants and their other products from secondary metabolism have been in high demand from the manufacturers of foods flavoring, fragrance, cosmetics, and pharmaceutical industries due to the growing interest of consumers in ingredients from natural sources. Many plants have been used for different purposes, such as food, drugs and perfumery. They have been screened for their potential uses as alternative remedies for the treatment of many infections and preservation of foods from the toxic effects of oxidants [1].

Lamiaceae is composed of more than 240 genera, most of them are highly aromatic due to the presence of external glandular structures, namely peltate and capitate trichomes that produce essential oils. According to Lawrence [2].

The Marrubium genus is represented by about 30 species [3]. Considered oil-poor species [2], little is known about their essential oils since more importance has been given to their maceration extract, which is consisted of the known and dominant active component marrubiin [4] .

Marrubium vulgare, commonly known as horehound or hoarhond, is native in Europe, Western Asia and North Africa, and is cultivated worldwide as a source for food flavoring 
and for medicinal purposes [5,6]. The name "marrubium'" refers to the bitter taste of the herb and "hoar" to the white pubescence covering the plant [7].

The chemical compositions of $\mathrm{M}$. vulgare essential oil from various origins have been the subject of many studies. The literature reveals the occurence of several chemotypes. From Lithuania, (Z)-b-farnesene, b-caryophyllene, (E)-2-hexenal, a-humulene and germacrene D were the main components of M. vulgare essential oil [8]. From Czech Republic, the main constituents of $\mathrm{M}$. vulgare essential oil were b-caryophyllene and germacrene D [9]. From different region of Iran, the main constituants of $\mathrm{M}$. vulgare essential tricyclene, b-pinene, bisabolol, b-elemone and isomenthon-8-thiol [10], b-bisabolene, 8-cadinene and isocaryophyllene [11], and bisabolene, b-caryophyllene, germacrene D and E-bfarnesene [12], caryophyllene oxide, b-caryophyllene and germacrene D [13].

Under Polish climatic conditions, Marrubium vulgare L. is aperennial plant. Medicinal properties of horehound have been long known and the origin of its use goes back to ancient Egypt. The medicinal raw material is the herb of horehound (Marrubi herba) [14]. The herb consists of whole or crushed flowering aerial parts of Marrubium vulgare L. [15], and it shows multiple effects on human organism [16-18]. The essential oil of Marrubium vulgare L. has a relaxant and expectorant effect as well as avasodilator [19]. The plant is reported to possess hypoglycemic [20], vasorelaxant [21], antihypertensive [22], analgesic [23,24], antiinflammatory [25], antioxidant activity [8,26], antiedematogenicactivity [27], and many other biological activities.

In Algeria folk medicine, it was used as hypotensive, hypoglycemic and cardiotonic. Recently, a large number of essential (volatile) oils and their constituents have been investigated for their biological activity, notably antibacterial and antioxidant properties $[28,29]$. Essential oils and their components are gaining increasing interest as a natural alternative to synthetic drugs [30], particularly against microbial agents because of their relatively safe status wide acceptance by consumers and their exploitation for potential multipurpose functional use.

The interest in plants with antibacterial properties has been revived because of current problems associated with the use of antibiotics [31]. Therefore, essential oils and other naturally occurring antibacterial are attractive to the food industry as well as imparting flavor [32]. More recently, the essential oil of this plant was advocated for their use as an antioxidant agent [26], but to the best of our knowledge, there are no reports on the antimicrobial properties and the cytotoxicity has been published. Therefore, this paper was conducted to investigate for the first time the antibacterial properties against clinical and pathogenic microorganisms and the cytotoxicity of M. vulgare essential oil grown in Algeria.

\section{MATERIALS AND METHODS}

\section{1. Plant material}

Plant materials (aerial parts) of M. vulgare L. were grown in the zone of Nigrine district of El-Ater in the wilaya of Tebessa, north east of Algeria. The whole plants were collected during the period of May to June 2009.

\section{2. Distillation of essential oil}

The samples were dried in the shade in natural air far from moisture and all pollutants for a fortnight in the room temperature. $100 \mathrm{~g}$ of ground rosemary were submitted to water 
distillation for $4 \mathrm{~h}$ using a Clevenger apparatus. The distilled essential oils were dried over anhydrous sodium sulfate, filtered and stored at $4{ }^{\circ} \mathrm{C}$.

\section{3. Gas chromatography}

The gas chromatographic analyzes were performed using a Hewlett Packard 6890 chromatograph equipped with a nonpolar column HP5MS (30 x $0.25 \mathrm{~mm}$ d.i., Film thickness 0.25 microns) and a flame ionization detector. The procedures conditions were as follow: carrier gas: nitrogen, flow rate $0.8 \mathrm{ml} / \mathrm{min}$, injector temperature: $250{ }^{\circ} \mathrm{C}$, detectors temperature: $300{ }^{\circ} \mathrm{C}$, temperature program: from 60 to 250 at $2{ }^{\circ} \mathrm{C} / \mathrm{min}$, with two levels: 8 minutes at $60{ }^{\circ} \mathrm{C}$ and $15 \mathrm{~min}$ at $280{ }^{\circ} \mathrm{C}$, injection of $0.4 \mu \mathrm{l}$ of pure essential oil and $1 \mu \mathrm{l}$ of absolute mode: mode split 1: 20. In order to determine retentions indices (RI) a series of nalkanes (C5-C28) mixture was analysed under the same operative conditions on HP-5 columns and the sample indices were calculated following Van den Dool and Kratz [33].

\section{4. Gas chromatography and mass spectrometry (GC/MS) analysis conditions}

The essential oils were analyzed on an apparatus of gas chromatography coupled to mass spectrometry brand Hewlet Packard 5973 A, equipped with an apolar capillary column (HP5MS, $30 \mathrm{~m} \times 0.25 \mathrm{~mm}$, phase thickness: $0.25 \mu \mathrm{m}$ ). the detection mode: electronic impact, ionization current: $70 \mathrm{eV}$, carrier gas: helium, flow rate: $0.7 \mathrm{ml} / \mathrm{mn}$, the source pressure: 10-7 mbar, interface temperature: $280{ }^{\circ} \mathrm{C}$, injection: $250{ }^{\circ} \mathrm{C}$, the programming of the oven: $2{ }^{\circ} \mathrm{C} / \mathrm{min}$ from $60^{\circ} \mathrm{C}$ to $280{ }^{\circ} \mathrm{C}$, with isothermal: $8 \mathrm{~min}$ at $60{ }^{\circ} \mathrm{C}$. and 15 minutes at $280{ }^{\circ} \mathrm{C}$. 0.1 to $0.2 \mu$ of pure essential oil and $1 \mu l$ absolutely were injected in split mode 1: 20. The identification of the essential oil constituents was based on a comparison of their retention times to $n$-alkanes, compared to published data and spectra of authentic compounds using their mass spectra compared to the Wiley version 7.0 library [3436]. as well as by comparison of the fragmentation patterns of mass spectra with those reported in the literature (Adams, 2007). The chromatographic conditions were identical to those used for GC analysis.

\section{5. Antibacterial assay dilution method}

The minimal inhibitory concentration (MIC) of essential oil was determined using the Mueller Hinton broth (MHB) dilution method [37]. All tests were performed in MHB supplemented with ethanol 5\% [38]. Bacterial strains were cultured overnight in MHB at 37 ${ }^{\circ} \mathrm{C}$. Tubes of MHB containing various concentrations of oils were inoculated with $10 \mu \mathrm{l}$ bacterial inoculums adjusted to $106 \mathrm{CFU} / \mathrm{ml}$. They were incubated under shaking conditions $(100-120 \mathrm{rpm})$ at $37^{\circ} \mathrm{C}$ for $24 \mathrm{~h}[39,40]$. Control tubes without tested samples were essayed simultaneously. The essays were performed in triplicate. The MIC was defined as the lowest concentration preventing visible growth $[41,42]$. 


\section{RESULTS AND DISCUSSION}

\section{1. Chemical composition of the essential oil}

Table 1. Chemical composition, retention indices (IR) and percentage composition of the M. vulgare essential oil.

\begin{tabular}{|c|c|c|c|c|}
\hline $\mathrm{N}^{\circ}$ & IR & Compound & $\%$ & Identification \\
\hline 1 & 823 & Trans -2-Hexanal & 0.75 & GC,GC/MS \\
\hline 2 & 903 & Heptanal & 0.1 & $\mathrm{GC}$ \\
\hline 3 & 906 & Santolina triene* & 0.71 & $\mathrm{GC}, \mathrm{GC} / \mathrm{MS}$ \\
\hline 4 & 937 & $\alpha$ - pinene & 9.37 & GC,GC/MS \\
\hline 5 & 946 & Camphene & 0.51 & $\mathrm{GC}, \mathrm{GC} / \mathrm{MS}$ \\
\hline 6 & 953 & Benzaldehyde & 2.31 & GC \\
\hline 7 & 962 & Sabinene & 0.37 & $\mathrm{GC}$ \\
\hline 8 & 983 & 1-Octen-3-ol & 2.35 & $\mathrm{GC}$ \\
\hline 9 & 990 & Myrecene & 0.47 & $\mathrm{GC}, \mathrm{GC} / \mathrm{MS}$ \\
\hline 10 & 995 & Octanol-3 & 0.64 & GC \\
\hline 11 & 1000 & Dichlorobenzene $<1,>*$ & 0.72 & GC,GC/MS \\
\hline 12 & 1022 & p-Cymene & 0.63 & $\mathrm{GC}, \mathrm{GC} / \mathrm{MS}$ \\
\hline 13 & 1029 & 1-8-cineole & 0.1 & $\mathrm{GC}$ \\
\hline 14 & 1038 & cis-Ocimene & 0.2 & $\mathrm{GC}$ \\
\hline 15 & 1055 & $\gamma$-Terpinene & 0.85 & GC,GC/MS \\
\hline 16 & 1113 & ß-Thujone & 0.81 & $\mathrm{GC}, \mathrm{GC} / \mathrm{MS}$ \\
\hline 17 & 1117 & Dehydro-sabina ketone* & 4.12 & $\mathrm{GC}, \mathrm{GC} / \mathrm{MS}$ \\
\hline 18 & 1122 & Camphor & 0.83 & GC,GC/MS \\
\hline 19 & 1219 & Carvone & 0.89 & $\mathrm{GC}$ \\
\hline 20 & 1224 & Piperitone & 3.27 & $\mathrm{GC}$ \\
\hline 21 & 1239 & Neral & 0.27 & $\mathrm{GC}, \mathrm{GC} / \mathrm{MS}$ \\
\hline 22 & 1250 & Geraniol & 0.92 & $\mathrm{GC}$ \\
\hline 23 & 1261 & Anethole $<\mathrm{E}>$ & 0.47 & $\mathrm{GC}, \mathrm{GC} / \mathrm{MS}$ \\
\hline 24 & 1275 & Geranial & 0.78 & $\mathrm{GC}$ \\
\hline 25 & 1282 & Thymol & 0.17 & $\mathrm{GC}, \mathrm{GC} / \mathrm{MS}$ \\
\hline 26 & 1284 & 2-Undecanone & 0.98 & $\mathrm{GC}, \mathrm{GC} / \mathrm{MS}$ \\
\hline 27 & 1291 & Cymen-7-ol $<\mathrm{p}>*$ & 0.95 & $\mathrm{GC}$ \\
\hline 28 & 1467 & $\alpha$-Humulene & 0.12 & $\mathrm{GC}$ \\
\hline 29 & 1481 & Germacrene D & 0.88 & $\mathrm{GC}$ \\
\hline 30 & 1491 & ß- Guaiene & 0.23 & $\mathrm{GC}, \mathrm{GC} / \mathrm{MS}$ \\
\hline 31 & 1501 & $\alpha$ - Farnesene & 0.23 & $\mathrm{GC}, \mathrm{GC} / \mathrm{MS}$ \\
\hline 32 & 1505 & $\gamma$-Cadinene & 0.44 & $\mathrm{GC}, \mathrm{GC} / \mathrm{MS}$ \\
\hline 33 & 1510 & Trans -calamenene & 0.21 & GC \\
\hline 34 & 1513 & $\delta$ - Cadinene & 3.13 & $\mathrm{GC}, \mathrm{GC} / \mathrm{MS}$ \\
\hline 35 & 1521 & Trans-Cadina-1-4-diene* & 0.21 & $\mathrm{GC}, \mathrm{GC} / \mathrm{MS}$ \\
\hline 36 & 1529 & $\alpha$-calacorene & 0.73 & $\mathrm{GC}$ \\
\hline 37 & 1538 & Germacrene D-4-ol & 9.61 & $\mathrm{GC}, \mathrm{GC} / \mathrm{MS}$ \\
\hline 38 & 1566 & Spathulenol & 0.87 & $\mathrm{GC}$ \\
\hline 39 & 1574 & Salvial-4(14)-en-1-one* & 0.96 & GC,GC/MS \\
\hline 40 & 1579 & ß- oplopenone & 0.63 & $\mathrm{GC}, \mathrm{GC} / \mathrm{MS}$ \\
\hline 41 & 1845 & trans-trans-Farnesyl acetate* & 0.8 & $\mathrm{GC}$ \\
\hline 42 & 1862 & cis-cis-Farnesyl acetone* & 0.98 & $\mathrm{GC}, \mathrm{GC} / \mathrm{MS}$ \\
\hline 43 & 1876 & Trans-cis-Farnesyl acetone* & 0.77 & $\mathrm{GC}, \mathrm{GC} / \mathrm{MS}$ \\
\hline 44 & 1895 & Nonadecane & 0.53 & $\mathrm{GC}, \mathrm{GC} / \mathrm{MS}$ \\
\hline 45 & 1921 & Phytol & 4.87 & $\mathrm{GC}, \mathrm{GC} / \mathrm{MS}$ \\
\hline 46 & 2102 & n-Heneicosane* & 0.8 & GC,GC/MS \\
\hline 47 & 2135 & Linoleic acid* & 1.0 & $\mathrm{GC}, \mathrm{GC} / \mathrm{MS}$ \\
\hline 48 & 2210 & Sclareol* & 0.81 & $\mathrm{GC}, \mathrm{GC} / \mathrm{MS}$ \\
\hline 49 & 2303 & Tricosane* & 0.96 & $\mathrm{GC}, \mathrm{GC} / \mathrm{MS}$ \\
\hline \multirow[t]{8}{*}{50} & 2327 & $\begin{array}{l}\text { 4,8,12,16Tetramethyl } \\
\text { heptadecan-4-olid* }\end{array}$ & 16.97 & $\mathrm{GC}, \mathrm{GC} / \mathrm{MS}$ \\
\hline & Total & & 82.46 & \\
\hline & & Grouped Compounds & & \\
\hline & & Monoterpene hydrocarbon & 12.61 & \\
\hline & & Oxygenated monoterpene & 9.46 & \\
\hline & & Sesquiterpene hydrocarbon & 5.58 & \\
\hline & & Oxygenated sesquiterpene & 13.17 & \\
\hline & & Others Compounds & 41.64 & \\
\hline
\end{tabular}




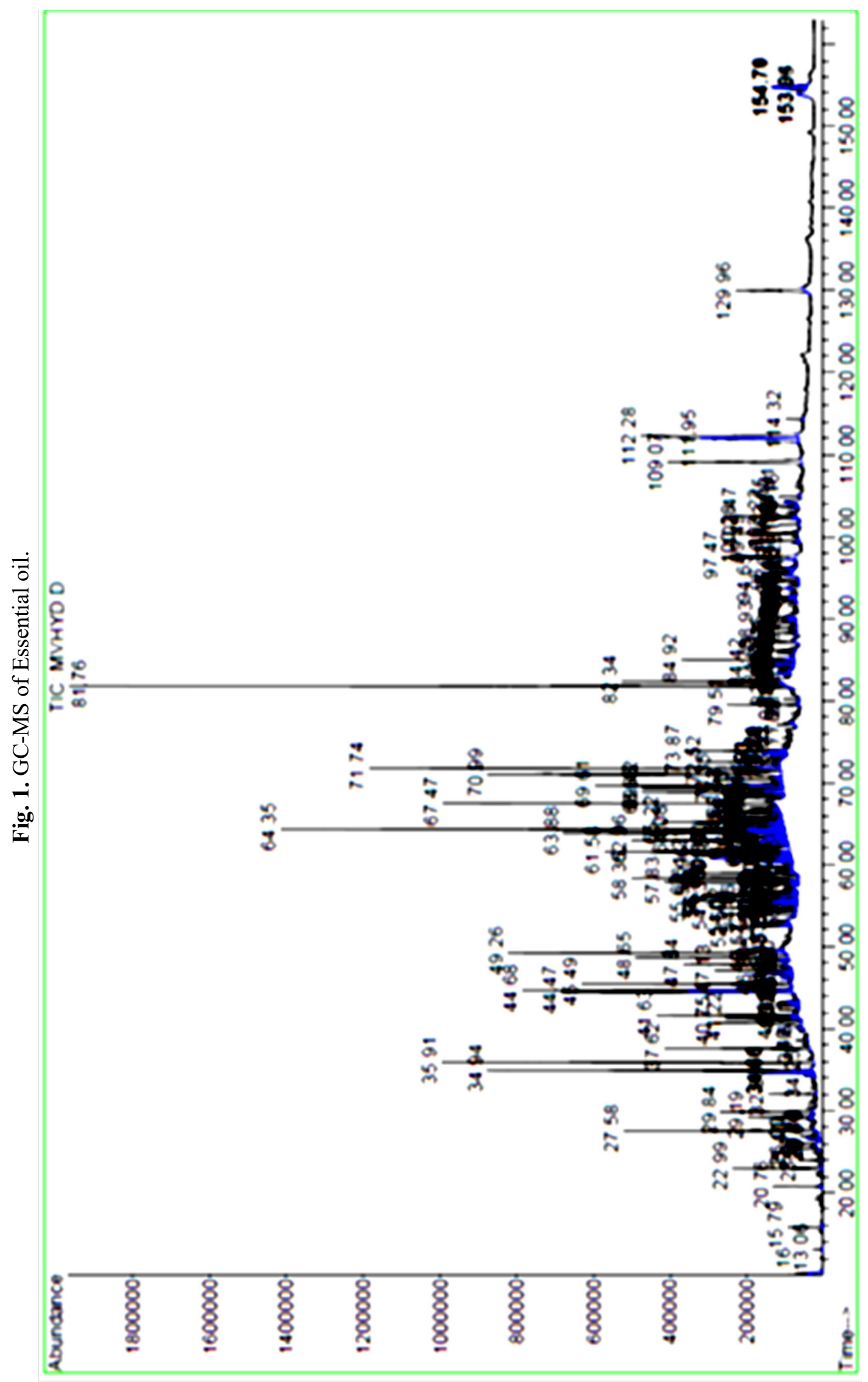


The study showed that the essential oil content in the dry herb of Marrubium vulgare L. was on average $0.05 \%$ [43]. Figure 1 shows the peaks of GC-MS spectrum. The search analysis in the digital library. The percentages and the retention indices of the identified components are listed in table 1 in the order of their elution on the HP-5MS column. GC-MS analysis of M.vulgare essential oil led to the identification of fifty (50) compounds, accounting for $82.42 \%$ of the total oil. The yield of essential oil obtained by hydrodistillation from aerial part of plant was $0.04 \%$.

Table 1 illustrates also the nine components with a supremacy of three major compononents: 4,8,12,16Tetramethyl heptadecan-4-olid (16.97\%), Germacrene D-4-ol (9.61 $\%), \alpha$ - pinene $(9.37 \%)$. They represnt about $36 \%$ of $56 \%$ and shows the different chemical groups with a dominance of other compounds with $41.64 \%$ of the total rate of volatil oil, followed by Oxygenated sesquiterpene with a lower rate $(13.17 \%)$ and, Monoterpene hydrocarbon (12.61\%) Oxygenated monoterpene (9.46\%), Sesquiterpene hydrocarbon $(5.58$ $\%$ ) respectively.

\subsection{Antibacterial activity}

The Antibacterial activities of $M$. vulgare essential oil against microorganisms examined in the present study and their potency were qualitatively and quantitatively assessed by the presence or absence of inhibition zones and zone diameter (DD), the medium inhibitory concentration (IC50) and the minimal inhibitory concentration (MIC) values. This essential oil displayed varied antibacterial activity. As can be seen from Table 2, essential oil inhibited the growth of bacterial for Gram (+)and Gram (-) bacterias, along with IC50 and MIC values ranging from $0.1-15 \mu \mathrm{l} / \mathrm{ml}$, respectively. the activities of essential oil tested against all strains (Bacillus subtilis (ATCC6663), Micrococcus luteus (ATCC9314), Escherichia coli (CIP54.8) and Klebsiella pneumoniae(CIP82.91)) has been revealed.

Table 2. Minimal inhibitory concentration (MIC) of essential oil from M. vulgare.

\begin{tabular}{|l|c|c|c|c|c|c|c|c|c|c|c|c|c|}
\hline The concentrations $(\boldsymbol{\mu l} / \mathbf{m l})$ & 0.1 & 0.2 & 0.3 & 0.4 & 0.5 & 1 & 2 & 3 & 4 & 5 & 10 & 15 \\
\hline \multicolumn{7}{|c|}{ Bacterias of Gram +} \\
\hline Bacillus subtilis (ATCC6663) & + & + & + & + & + & + & + & + & + & + & + & - \\
\hline Micrococcus luteus (ATCC9314) & + & + & + & + & + & + & + & + & + & + & - & - \\
\hline
\end{tabular}

\section{CONCLUSION}

The essential oil of M. vulgare showed significant antimicrobial activity. Analysis by GC-MS and GC/FID of M. vulgare essential oil of eastern Algeria and tested represent an inexpensive source of natural antibacterial substances for use in pathogenic systems to prevent the growth of bacteria and extend the shelf life of the processed food. 


\section{ACKNOWLEDGMENTS}

The authors gratefully acknowledge Mrs Aicha Hassani professor at The University of ENS Kouba Algiers for her help and advice, and the Technical staff in the laboratory of both Laboratoire de Molécules Bio-active et Valorisation de la Biomasse, École Normale Supérieure Kouba-Algiers; and Laboratoire de Chromatographie, Faculté de Chimie, USTHB, Algiers, Algeria for their support.

\section{References}

[1] Barlow S. M., Hudson B. J. F., (Ed.)., Elsevier, Amsterdam 1990, pp. 23.

[2] B. M. Lawrence, Science. Edits., R. M. Harley and T. Reynolds, Royal Botanic Gardens, Kew, 1992, pp. 399-436.

[3] M. S. Abu-Asaband, R. D. Cantlno, In: Advances In Lablate Science. Edits. R, M. Harley and T. Reynolds, Royal Botanic Gardens, Kew, 1992, pp. 97-112.

[4] V. Schiemper, A. Ribas, M. Nlcolau, V. Cechinel-Fliho, Phytomedecine 3 (1996) 211-216.

[5] W. Letchamo, S. Mukhopadhyay, J. Hortic. Sci. 72 (1997) 741-748.

[6] S. Sahpaz et al., Journal of Ethnopharmacology 79 (2002) 389-392.

[7] J. E.Slmon, A. F. Chadwickand, L. E.Craker, Herbs-anIndexedblbllograptry 1971-1980, Elsevler, Amsterdam 1984, p. 48,

[8] A. Abadi, A. Hassani, International Letters of Chemistry, Physics and Astronomy 9(1) (2013) 17-24.

[9] Nagy M., Svajdlenka E.,J. Essent Oil Res. 10 (1998) 585-587.

[10] Saleh M. M., Glombitza K. W., Planta Med 55 (1989) 105-108.

[11] Morteza-Semnani K., Saeedi M., J. Essent Oil Bearing Plants 7 (2004) 239-242.

[12] Asadipour A, Mehrabani M, Nazeri V, Tabarraii M., Ulum-i-Daroei 2 (2005) 77-82.

[13] Khanavi M., Ghasemian L., Hosseiny Motlagh E., Hadjiakhoondi A., Shafiee A., Flav. Fragr. J. 20 (2005) 324-326.

[14] Wolski T., Matosiuk D., Baj T., Ziewiec A., Postepy Fitoterapii 1 (2007) 39-45.

[15] Polish Pharmacopoeia VIII. PTFarm., Warszawa, 2008, 2249-2250.

[16] Bradley P. R., British Herbal Medicine Association 1 (1992) 218-220.

[17] El Bardai S., Wibo M., Hamaide M-Ch., Lyoussi B., Quetn-Leclerq J., Morel N., British Journal of Pharmacology 140 (2003) 1211-1216.

[18] Kohlmünzer S., Farmakognozja, Wydawnictwo Lekarskie PZWL Warszawa, 2007, 308.

[19] Wyk B. E., Wink M., Rośliny lecznicze świata, MedPharm Polska, 2008, 198.

[20] Roman R. R., Aharcon A.F., Lara L.A., Flores S. J.,L., Arch. Med. Res. 23(1) (1992) 59-64.

[21] El-Bardai S., Morel N., Wibo M., Fabre N., Llabres G., Lyoussi B., Quetin L., Plant Med 69(1) (2003) 75-77. 
[22] El-Bardai S., Lyoussi B., Wibo M., Morel N., Clin Exp Hyprtens 26(6) (2004) 465-474.

[23] DeSouza M. M., DeJesus R. A. P., Cechinel-Filho V., Schlemper V., Phytomed 5(2) (1998) 103-107.

[24] Sahpaz S., Garbacki N., Tits M., Bailleul F., J. Ethnopharmacol 79(3) (2002) 389-392.

[25] Schlemper V., Ribas A., Nicolau M., Cechinel-Filho V., Phytomedicine 3 (1996) 211-216.

[26] Kadri A., Zarai Z., Bekir A., Gharsallah N., Damak M., Gdoura R., African Journal of Biotechnolgy 10(198) (2011) 3908-3914.

[27] Stulzer H. K., Tagliari M. P., Zampirolo J. A., Cechinel-Filho V., Schlemper V. J. Ethnopharmacol 108(3) (2006) 379-392.

[28] Baratta M. T, Dorman H. J. D., Deans S. G., Figueiredo A. C., Barroso J. G., Ruberto G., Flav. Fragr. J. 13 (1998) 235-44.

[29] Bounatirou S., Smiti S., Miguel M. G., Faleiro L., Rejeb M. N., Neffati M., Costa M. M., Figueiredo A. C., Barroso J. G., Pedro L. G., Food Chem 105 (2007) 146-155.

[30] Fabio A., Cermelli C., Fabio G., Nicoletti P., Quaglio P., Phytother Res. 21 (2007) 374-377.

[31] Voravuthikunchai S. P., Sririrak T., Limsuwan S., Supawita T., Iida T., Honda T., J. Health Sci. 51(5) (2005) 590-596.

[32] Burt S., International Journal of Food Microbiology 94 (2004) 223-253.

[33] H. Van den Dool, P. D. Kratz, J. Chromatogr. 11 (1963) 463.

[34] F. Macchioni, P. L. Cioni, G. Flamini, I. Morelli, S. Maccioni, M. Ansaldi, Flavour Frag. J. 18 (2003) 139.

[35] V. Roussis, P. Katerina, V. Constantinos, P. V. Catherine, O. Antonio, J. Essent. Oil Res. 13 (2001) 118.

[36] R. P. Adams, Identification of Essential Oils by Ion Trap Mass Spetroscopy, Allured Publishing Corporation, Carol Stream, IL, USA, 1995.

[37] May J., Chan C. H., King A., Williams L., French G. L., J. Antimicrobial Chemoter 45 (2000) 639-643.

[38] Ferreira A., Proenca A. C., Serralheiro C. M. L. M., Araujo M. E. M., J. Ethnopharmacology 108 (2006) 31-37.

[39] Saidana D., Mahjoub M. A., Boussaada O., Chriaa J., Cheraif I., Daami-Remadi M., Mighri Z., Helal A. N., Microbiology Res. 163 (2008) 445-455.

[40] Boussaada O., Ammar S., Saidana D., Chriaa J., Chraif I., Daami-Remadi M., Helal A. N., Mighri Z., Microbiology Res. 163 (2008) 87-95. 
[41] Hammer K. A., Carson C. F., Riley T. V., J. App. Microbiology 86 (1999) 985-990.

[42] Delaquis P. J., Stanich K., Girard B., Mazza G., Int. J. Food Microbiology 74 (2002) 101-109.

[43] Zawiślak G., Herba Pol. 55(3) (2009) 63-68. 